\title{
Occurrence characteristics of two sibling species, Pseudodiaptomus inopinus and Pseudodiaptomus poplesia (Copepoda, Calanoida, Pseudodiaptomidae), in the Mankyung River estuary, South Korea
}

\author{
Eun-Ok Park ${ }^{1,2^{*}}$, Jeffery R Cordell ${ }^{3}$ and Ho Young Soh ${ }^{4}$
}

\begin{abstract}
Background: Abundances of two closely related Pseudodiaptomus species, Pseudodiaptomus inopinus and Pseudodiaptomus poplesia, and salinity, temperature, and chlorophyll (Chl) a levels were measured monthly at a station in the Mankyung River estuary, South Korea, through a spring tide flood-ebb series.

Results: Both species occurred mostly under mesohaline to polyhaline conditions throughout the year. P. poplesia was abundant under winter polyhaline conditions and reached its peak abundance under mesohaline conditions in spring, when the Chl a concentration was highest. P. inopinus had lower densities than P. poplesia at all salinities in spring and had peak densities under mesohaline and polyhaline conditions in November, when a second Chl $a$ peak concentration occurred. Egg-bearing females of both P. poplesia and P. inopinus were present in spring and fall, but the ratio of gravid females of the former was higher under mesohaline and polyhaline conditions in April and May, while that of the latter was higher under polyhaline conditions in March.
\end{abstract}

Conclusion: These facts indicate that abundances of $P$. poplesia and $P$. inopinus may be controlled by Chl $a$ concentrations and salinity conditions.

Keywords: River estuary; Copepods; Salinity gradient; Chlorophyll a concentration; Co-occurrence

\section{Background}

Estuaries are dynamic and variable environments, and the spatiotemporal distribution of estuarine species is affected by environmental factors such as temperature and salinity. These fluctuations in environmental factors may also result in a low level of species diversity and promote the coexistence of congeneric species (Jeffries 1962; Wooldridge and Melville-Smith 1979; Sullivan and McManus 1986). Most studies on the coexistence of zooplankton species in estuarine and coastal environments addressed the mechanisms responsible for interspecific competition, spatial segregation, and reproductive isolation (Greenwood 1981;

\footnotetext{
* Correspondence: ej0731@daum.net

'Department of Oceanography, Chonnam National University, Gwangju 500-757, South Korea

2Department of Life Science, Hanyang University, Seoul 133-791, South Korea Full list of author information is available at the end of the article
}

Ueda 1987; Laprise and Dodson 1993). Strategies by which congeneric species may avoid or reduce direct competition include maintaining different temporal and spatial distributions and partitioning available food resources by selective feeding (Greenwood 1981; Ueda 1987; Laprise and Dodson 1993).

The mesozooplankton of many estuaries are dominated by calanoid copepods, particularly the demersal calanoid family Pseudodiaptomidae, which accounts for $70 \%$ of the abundance of calanoid copepods in the Mankung River estuary, South Korea. In Korean estuaries, five species of the genus Pseudodiaptomus have been recorded, and two species, Pseudodiaptomus inopinus and Pseudodiaptomus poplesia, are predominant (Suh et al. 1991; Soh et al. 2001). Of these two species, $P$. inopinus is more common and widespread in brackish 


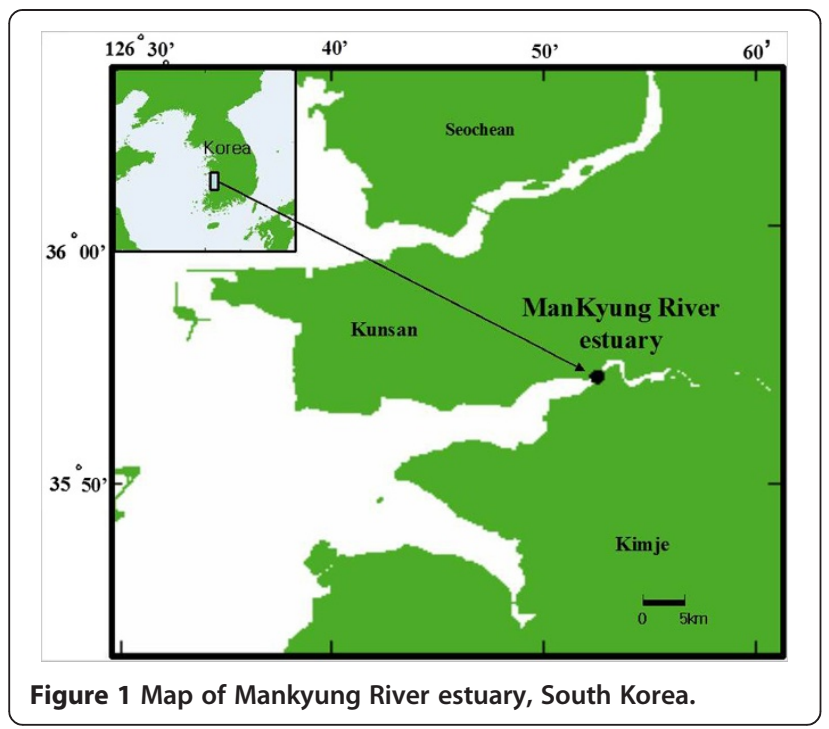

and/or freshwaters of northeast Asia in general and Korea in particular (Chen and Zhang 1965; Shen and Song 1979; Chang and Kim 1986; Oka et al. 1991; Uye et al. 2000; Lee et al. 2007; Chang 2009; Sakaguchi et al. 2011). In contrast, P. poplesia has only been documented on the Yellow Sea side of the Korean Peninsula and in estuaries of the South China Sea (Shen and Song 1979; Soh et al. 2001; Tan et al. 2004; Lee et al. 2007; Shang et al. 2007; Chang 2009). In addition to its wide occurrence in Asia, P. inopinus was introduced into the Columbia River estuary on the Pacific coast of North America between 1980 and 1990, presumably by way of ballast water of ships, and has rapidly expanded its range since then (Cordell et al. 1992, 2008; Cordell and Morrison 1996; Bollens et al. 2002). In estuaries where it was introduced, $P$. inopinus tends to seasonally dominate the mesozooplankton and may have resulted in changes in the food webs of those estuaries (Cordell

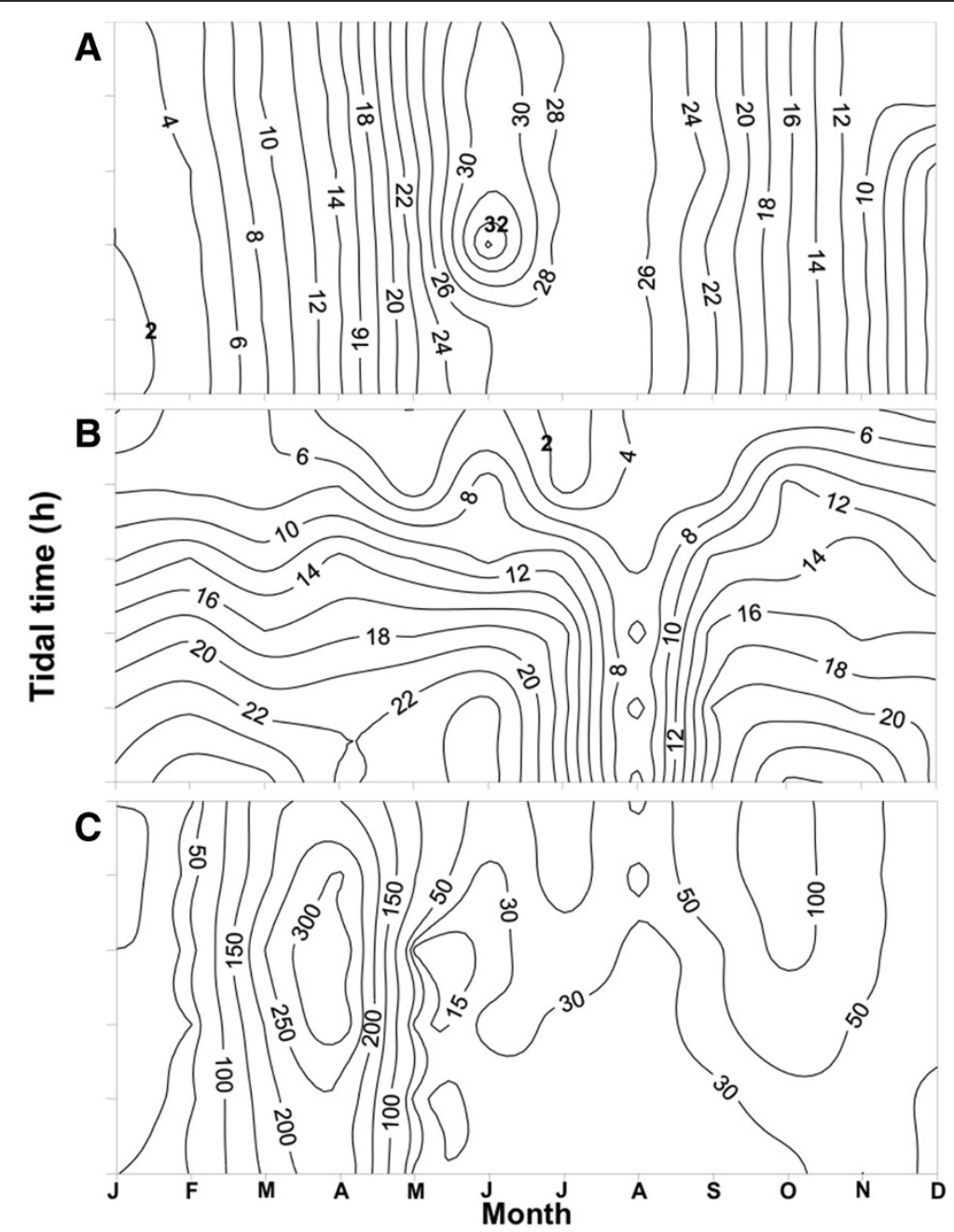

Figure 2 Monthly spatial and temporal variations in water temperature, salinity, and chlorophyll $a$ concentration in the estuary. (A) Temperature $\left({ }^{\circ} \mathrm{C}\right)$, (B) salinity, and (C) chlorophyll a $(\mu \mathrm{g} / \mathrm{L})$. 
and Morrison 1996; Cordell et al. 2007). Several studies focused on the biology of both native and introduced populations of P. inopinus (Ueda et al. 2004; Cordell et al. 2007), while little or no information of this type exists for P. poplesia.

In this study, we examined the seasonal occurrence patterns of P. inopinus and P. poplesia, the dominant copepods in the Mankyung River estuary, in order to document patterns of occurrence in relation to temperature, salinity, food, and specifically chlorophyll (Chl) a concentrations. The goal of this study was to better understand how these two closely related species coexist in the estuary and provide more information regarding their biology.

\section{Methods}

The Mankyung River estuary is located on the central portion of the west coast of Korea (Figure 1). The estuary is shallow and wellmixed, with semidiurnal tides that occur over a range of about $6 \mathrm{~m}$. Annual rainfall in the area is $c a .1,371 \mathrm{~mm}$, mainly occurring during the summer rainy season.
Zooplankton were collected monthly between January and December 2000 at one station in the Mankyung River estuary (Figure 1). Sampling was done during one spring tide flood-ebb cycle at approximately 1 -h intervals. Zooplankton samples were obliquely towed from near the bottom to the surface using a weighted conical net (with a mouth diameter of $45 \mathrm{~cm}$ and a mesh size of $200 \mu \mathrm{m})$. Samples were immediately preserved in a 5\% neutralized formalin/seawater solution. In the laboratory, Pseudodiaptomus species were sorted and counted under a dissecting microscope. Counts were converted to individuals per cubic meter of seawater (ind. $/ \mathrm{m}^{3}$ ).

Water temperature and salinity were measured using a T-S meter (Model 30, YSI, Yellow Springs, OH, USA) from the surface to the bottom at $1-\mathrm{m}$ intervals. To measure the $\mathrm{Chl} a$ concentration, $1,000 \mathrm{ml}$ of seawater was collected from the surface layer once during each sampling. Chl $a$ was extracted by grinding the filter paper in a dark room and placing it in $90 \%$ acetone, as recommended by SCOR-UNESCO (1980). The extracted sample was centrifuged, and the absorbance of the

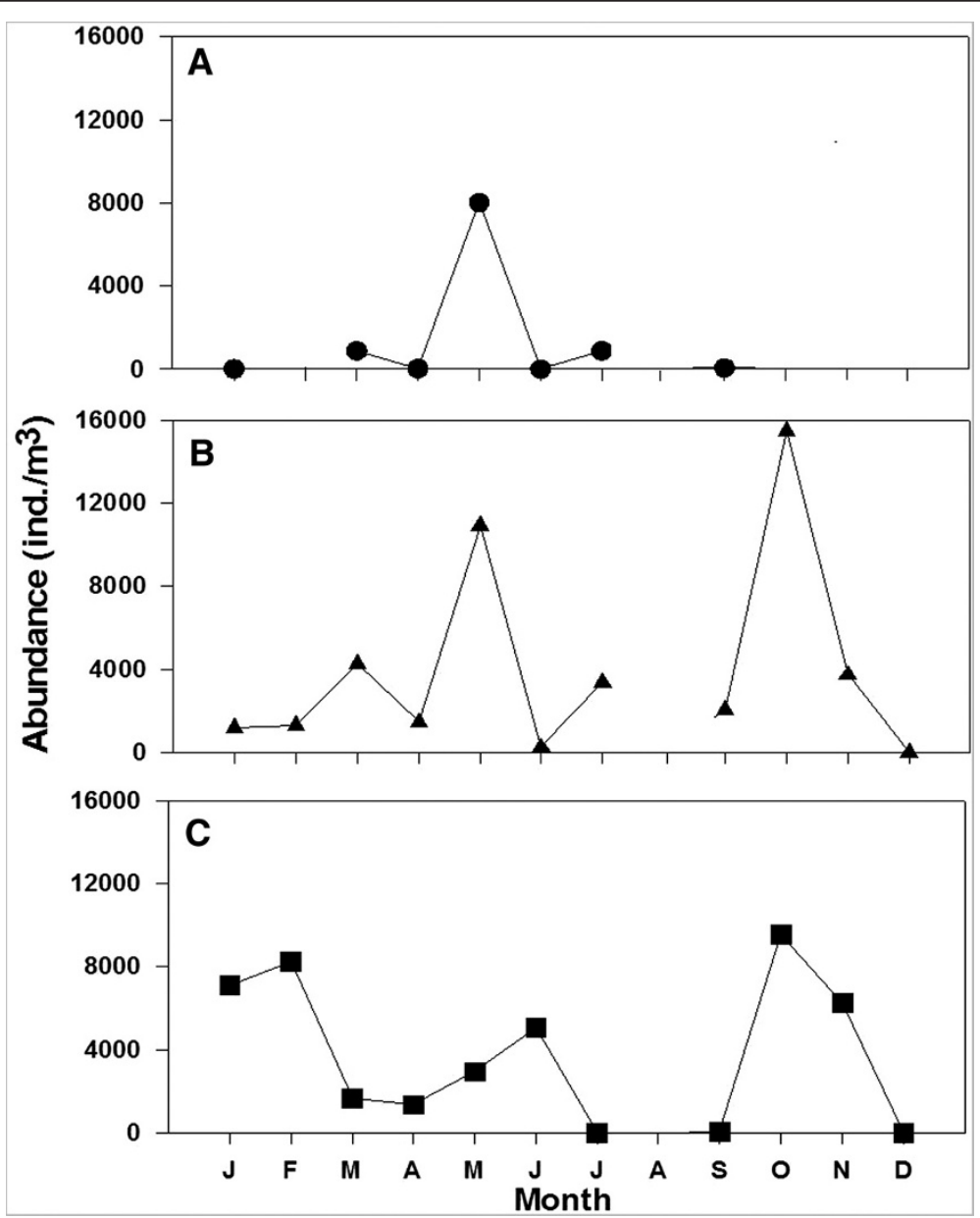

Figure 3 Seasonal variations in abundances (ind. $/ \mathrm{m}^{3}$ ) of P. poplesia. (A) Oligohaline, (B) mesohaline, and (C) polyhaline. 
supernatant was measured at 750, 664, 647, and $630 \mathrm{~nm}$ using a spectrophotometer (UNICAM Helios Alpha, Gloucester, UK). Water column conditions for each sample were designated as oligohaline ( 0 to 5 practical salinity unit (psu)), mesohaline (5 to $18 \mathrm{psu}$ ), and polyhaline ( $>18 \mathrm{psu}$ ) on the basis of Ekman's classification system (Day et al. 1989).

To evaluate correlations between abiotic factors and the abundances of the two Pseudodiaptomus species, data were $\log (x+1)$-transformed, and a multivariate regression model analysis (Afifi et al. 2004) was conducted using SAS version 9.2 (Cary, NC, USA). For correlations between the abundances of $P$. poplesia and P. inopinus, Pearson's correlation coefficient was used.

\section{Results}

\section{Water temperature and salinity}

The mean temperature ranged from a high of $29.6^{\circ} \mathrm{C} \pm$ $1.6^{\circ} \mathrm{C}$ (standard deviation) in August 2000 to a low of $2.3^{\circ} \mathrm{C} \pm 3.1^{\circ} \mathrm{C}$ in February 2000 (Figure 2A). Water temperature varied seasonally: winter (December, January, and February) temperatures ranged from $2.3^{\circ} \mathrm{C}$ to $3.8^{\circ} \mathrm{C}$; spring (March, April, and May) temperatures ranged from $9.1^{\circ} \mathrm{C}$ to $22.9^{\circ} \mathrm{C}$; summer (June, July, and August) temperatures remained above $26^{\circ} \mathrm{C}$; and fall (September, October, and November) temperatures ranged from $10.7^{\circ} \mathrm{C}$ to $22.4^{\circ} \mathrm{C}$. Differences between the surface and bottom temperatures were $<2^{\circ} \mathrm{C}$, except in June, when they were $<4^{\circ} \mathrm{C}$.

Salinity ranged from 0.8 to $27.7 \mathrm{psu}$, but there were seasonal differences in this parameter. In particular, salinities were lower during the rainy season. In July, conditions were oligohaline to mesohaline, with salinities remaining below $18 \mathrm{psu}$, while in August, only oligohaline conditions occurred $(<5 \mathrm{psu})$. During the dry season in October to December, salinities increased again and, for the most part, remained in the mesohaline to polyhaline ranges regardless of the tide or sampling interval. Differences between the surface and bottom layers were also $<1$ psu (Figure 2B).

\section{Chl $a$ concentrations}

Chl $a$ concentrations ranged from 6.8 to $342.7 \mu \mathrm{g} / \mathrm{L}$ during the study period and were more than three times greater during the spring phytoplankton bloom than during the other seasons (Figure 2C). In oligohaline
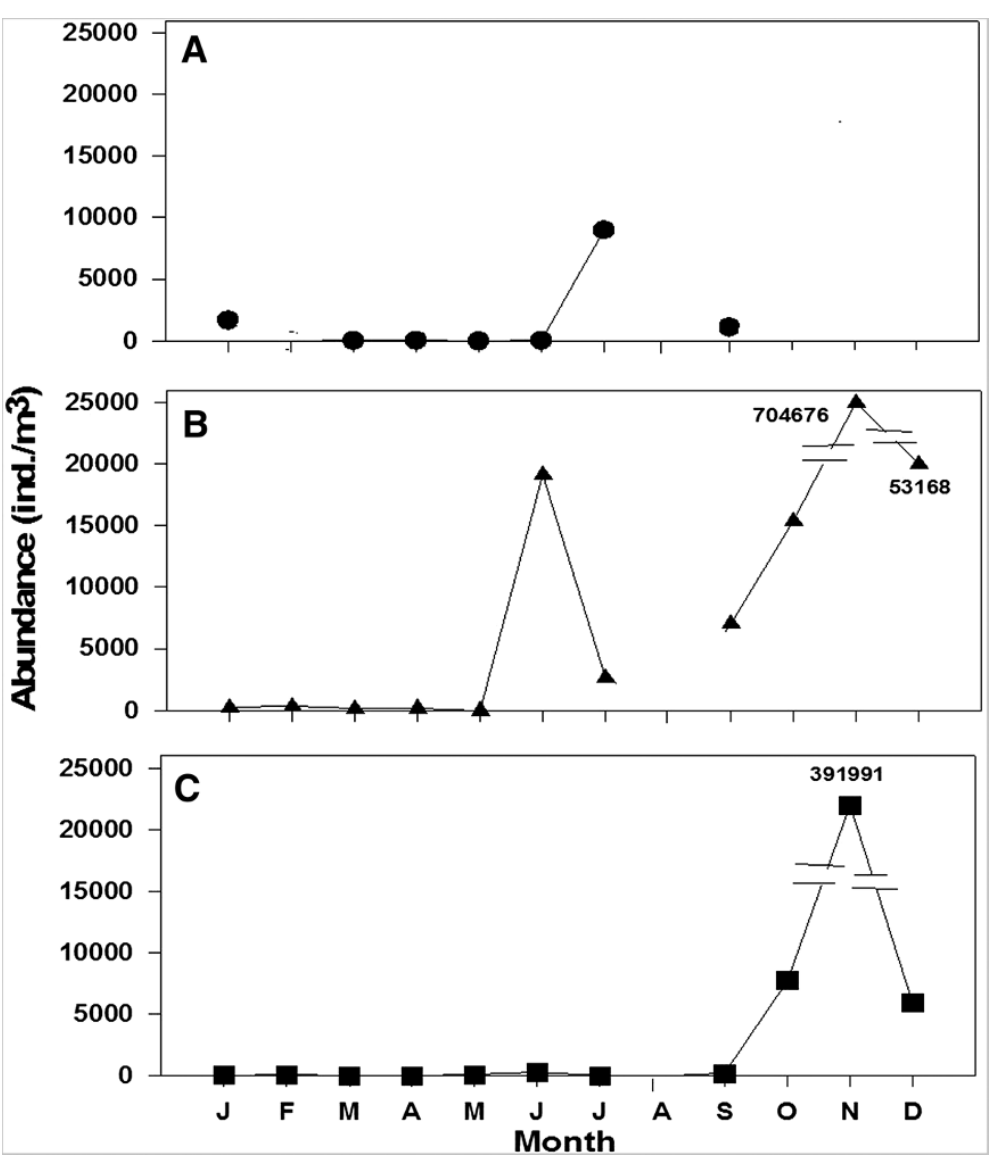

Figure 4 Seasonal variations in abundances (ind./ $\mathrm{m}^{3}$ ) of P. inopinus. (A) Oligohaline, (B) mesohaline, and (C) polyhaline. 
conditions, concentrations ranged from 16.0 to $200.1 \mu \mathrm{g} / \mathrm{L}$, with the highest concentration in April and the lowest in January. In mesohaline conditions, concentrations ranged from 21.5 to $272.9 \mu \mathrm{g} / \mathrm{L}$ and, as in oligohaline conditions, were highest in April and lowest in January. Under polyhaline conditions, concentrations of Chl $a$ were highest in May $(94.0 \mu \mathrm{g} / \mathrm{L})$ and lowest in November $(7.1 \mu \mathrm{g} / \mathrm{L})$. Overall mean Chl $a$ concentrations were found under mesohaline conditions.

\section{Seasonal occurrence patterns of $P$. inopinus and \\ P. poplesia}

$P$. inopinus and P. poplesia occurred throughout the salinity range and during the entire study period, with the exception of the summer rainy season. The density of $P$. poplesia ranged from 30 to 8,022 ind. $/ \mathrm{m}^{3}$ under oligohaline conditions in spring, when the Chl a concentration was $>162 \mu \mathrm{g} / \mathrm{L}$, but decreased to 7 to $895 \mathrm{ind} . / \mathrm{m}^{3}$ in June and July with a decline in Chl $a$ concentrations $(<42.3 \mu \mathrm{g} / \mathrm{L})$ and was lowest $\left(<1\right.$ ind. $\left./ \mathrm{m}^{3}\right)$ in August (Figure 3A). After that, the density increased $\left(<62\right.$ ind. $\left./ \mathrm{m}^{3}\right)$ in October, when the Chl $a$ concentration was $>86.8 \mu \mathrm{g} / \mathrm{L}$, but then declined to $<17$ ind. $/ \mathrm{m}^{3}$ during the winter months. Densities of $P$. inopinus were somewhat higher than those of $P$. poplesia under oligohaline conditions, except in spring (Figures 4A and 5A) and October through December, when neither species occurred. Under mesohaline conditions, the density of $P$. inopinus increased after spring, with a peak density of 704,676 ind./ $\mathrm{m}^{3}$ in November (Figure 4B). Under mesohaline and polyhaline conditions, $P$. inopinus densities remained high during the fall months, when Chl $a$ concentrations were lower than in spring (Figures 4B,C and 5B,C). In contrast, P. poplesia did not occur under mesohaline conditions in November and December or in polyhaline conditions in December (Figures 3B,C and 5B,C). Results of the multivariate regression analysis of correlations of environmental factors, such as temperature, salinity, and Chl $a$, with densities of the twoPseudodiaptomus species showed that densities of $P$. poplesia and $P$. inopinus were significantly affected by both salinity $(p<0.05)$ and Chl $a$ concentrations $(p<0.001)$, but were not significantly affected

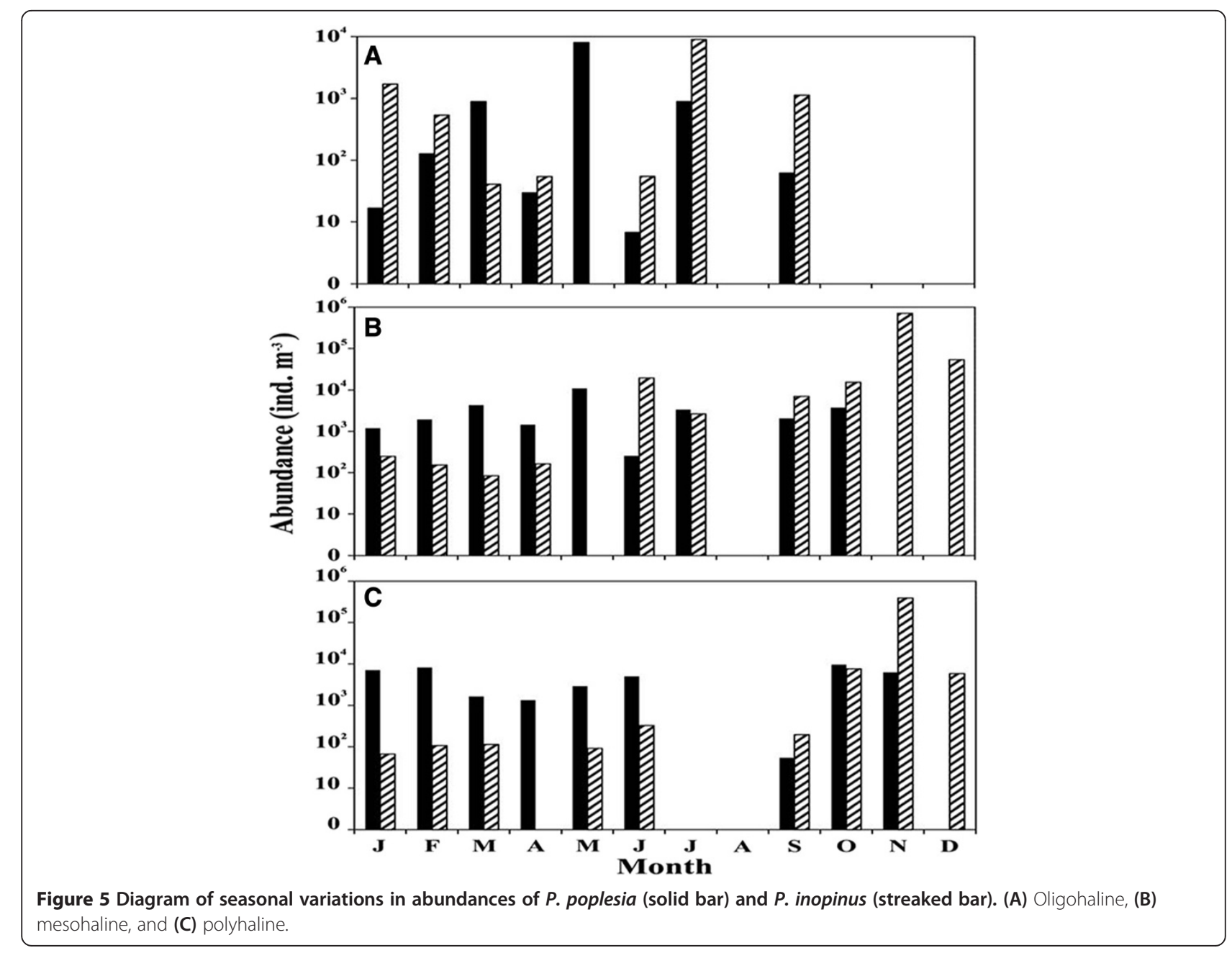


Table 1 Results of the multivariate regression model analysis of $P$. poplesia and $P$. inopinus

\begin{tabular}{|c|c|c|c|c|c|c|}
\hline & & & & & Wil & da \\
\hline & Coefficient & Standard error & Coefficient & Standard error & Value & $p$ value \\
\hline Intercept & -0.05488 & 1.21296 & 4.22593 & 1.41962 & & \\
\hline Temperature & 0.02418 & 0.04065 & -0.05326 & 0.04758 & 0.96879 & 0.1435 \\
\hline Salinity & 0.27194 & 0.05029 & 0.12803 & 0.05886 & 0.93223 & 0.0295 \\
\hline Chlorophyll $a$ & 0.01006 & 0.00460 & -0.01297 & 0.00539 & 0.81822 & 0.0002 \\
\hline
\end{tabular}

by temperature $(p>0.05)$ (Table 1$)$. In particular, densities of $P$. poplesia were higher than those of $P$. inopinus at high Chl $a$ concentrations, while the latter species was more abundant under relatively low $\mathrm{Chl} a$ concentrations.

Sex ratio and gravid females of $P$. poplesia and $P$. inopinus Males of $P$. poplesia were more abundant than females across the entire salinity range throughout the study period, except under oligohaline conditions in April, and the ratio of males to females reached $50 \%$ under mesohaline and polyhaline conditions in spring (Figure 6).
Males of $P$. inopinus were more abundant than females throughout the study period and across the entire range of salinity, but the ratio of males to females exceeded $50 \%$ under oligohaline conditions in January, mesohaline conditions in late fall and winter, and polyhaline conditions in early winter (Figure 7).

Gravid females of P. inopinus appeared in oligohaline conditions only in March, July, and September and accounted for $>50 \%$ of all females present in September (Figure 8). Under mesohaline conditions, they occurred in June to October, and under polyhaline conditions,

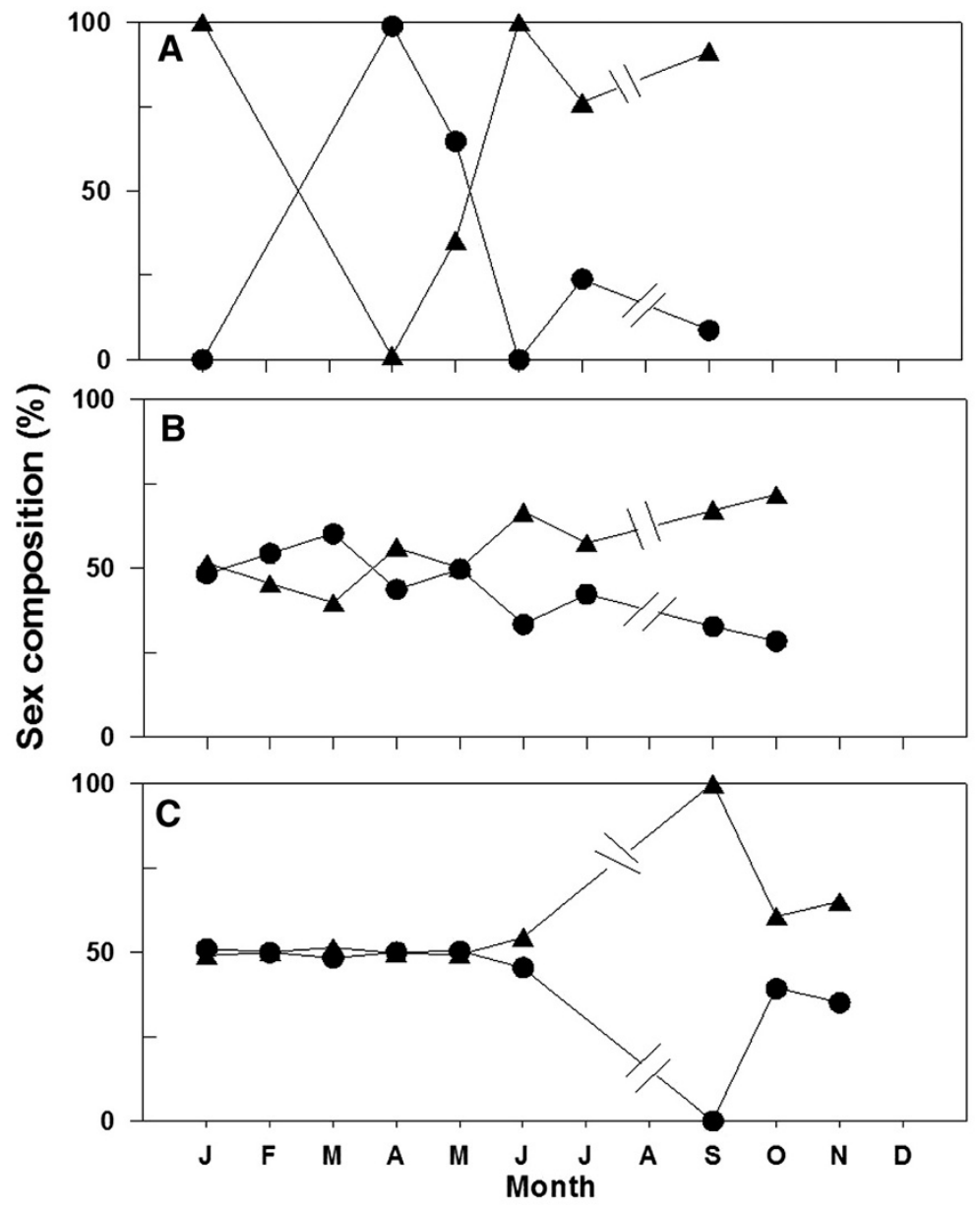

Figure 6 Seasonal variations in the adult sex composition of P. poplesia. (A) Oligohaline, (B) mesohaline, and (C) polyhaline. Circle, female; triangle, male. 


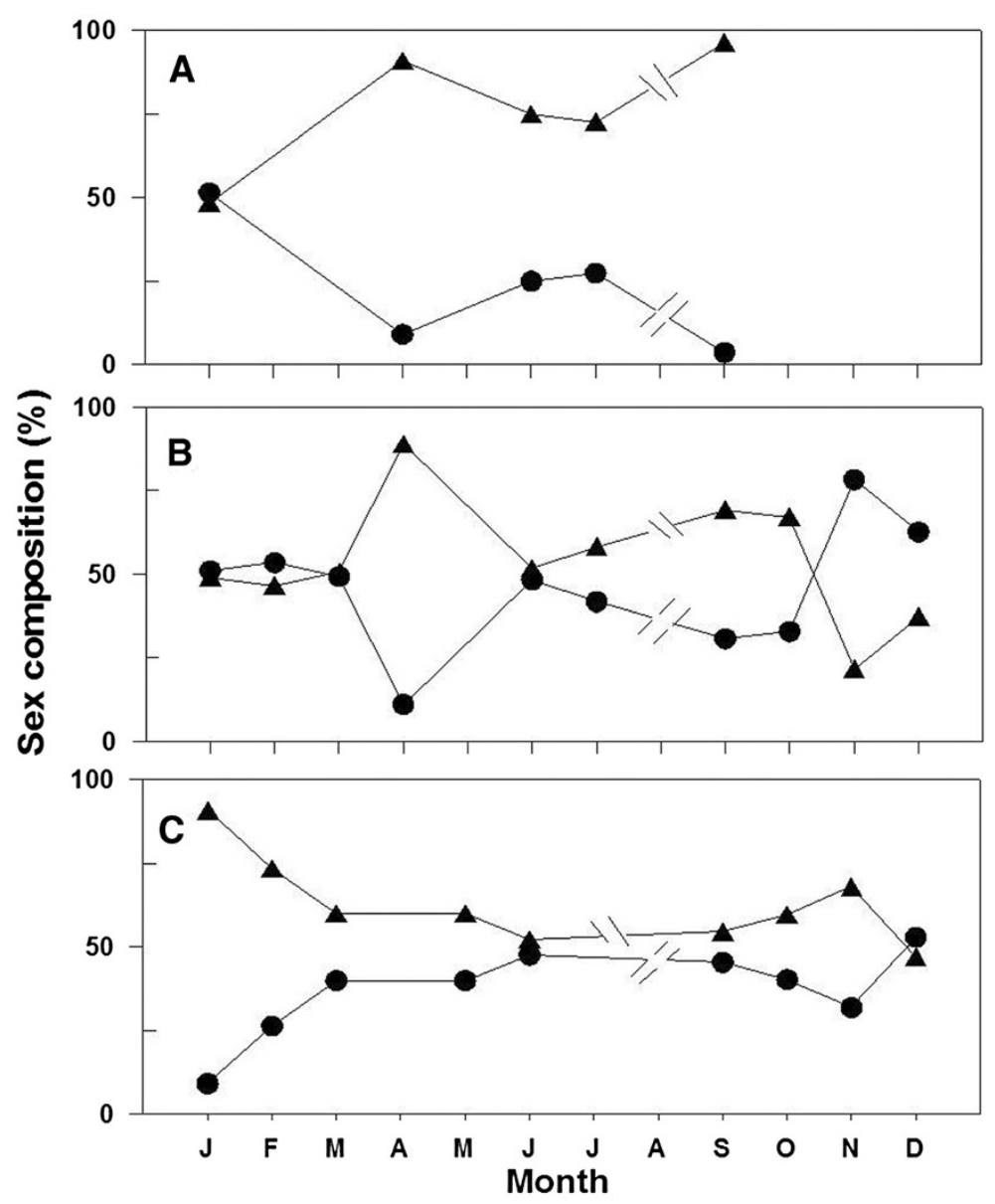

Figure 7 Seasonal variations in the adult sex composition of $\boldsymbol{P}$. inopinus. (A) Oligohaline, (B) mesohaline, and (C) polyhaline. Circle, female; triangle, male.

they occurred only in June and October, and $>50 \%$ of all females were gravid in October. Gravid females of P. poplesia were present in March to October, comprising $3 \%$ to $72 \%$ of the female population (Figure 9 ). Under oligohaline conditions, $>50 \%$ of the female population was gravid in July and also under mesohaline and polyhaline conditions in April and May. Percentages of gravid females of $P$. poplesia were very low during fall months, and they did not occur under oligohaline conditions.

\section{Discussion}

In the Mankyung River estuary of South Korea, two sibling species, P. inopinus and P. poplesia, co-occurred throughout the year under all salinity categories except in August, when most estuarine zooplankton are swept downstream because of increased freshwater flows during the rainy season (see Suh et al. 1991). In addition, water temperatures in the Mankyung River estuary were similar during spring and fall, being within the range of $9.0^{\circ} \mathrm{C}$ to $23.6^{\circ} \mathrm{C}$ in both seasons, while $\mathrm{Chl} a$ concentrations were higher in spring than fall (Figure 2). However, this study showed that the abundance of $P$. inopinus was affected by the presence or absence of $P$. poplesia and/or low water temperatures, with no relation to salinity. However, abundances of the two species significantly differed with salinity and $\mathrm{Chl} a$ concentrations. Our finding that the abundances of the two species significantly differed on the basis of Chl $a$ concentrations could be due to their distinct feeding strategies. In the case of Pseudocalanus minutus, non-living particles, mainly dead organisms or simply detritus, are supplementary food sources and serve as a basic food source (Poulet 1976). Likewise, the consumption of particles by the two Pseudodiaptomus species may be associated with changes in both the total concentration and the composition of suspended particulate materials, and nonoverlapping food niches are possible if two copepod species differ in size (Hutchinson 1967; Maly and Maly 1974). Sandercock (1967) suggested that the coexistence of species depends upon the additive effects of two factors or 


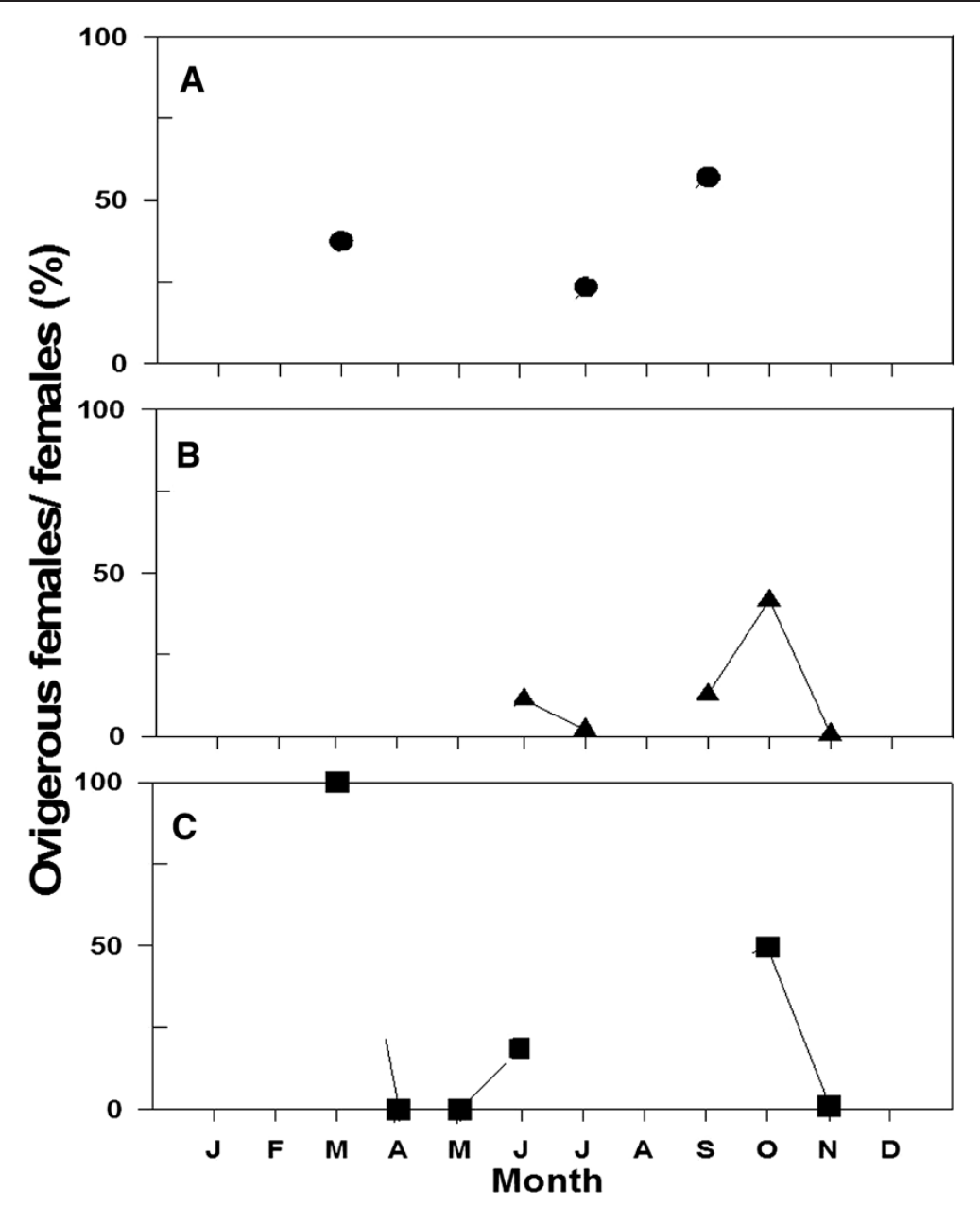

Figure 8 Seasonal variations in the composition of ovigerous adult females of $P$. inopinus. (A) Oligohaline, (B) mesohaline, and (C) polyhaline.

mechanisms. Therefore, the coexistence of $P$. poplesia and $P$. inopinus could be controlled by dietary differences and the salinity gradient.

P. inopinus was introduced (probably via ballast water) to a number of estuaries along the Pacific coast of the USA, where it has become the dominant brackisholigohaline mesozooplankton species and has probably altered estuarine food webs (Cordell and Morrison 1996; Cordell et al. 2007). In northeastern Pacific estuaries, it reaches peak abundances in late summer/early autumn $\left(17.4^{\circ} \mathrm{C}\right.$ to $\left.20.8^{\circ} \mathrm{C}\right)$ over a salinity range of 0 to $10 \mathrm{psu}$ (Cordell et al. 2007, 2010). Pseudodiaptomus koreanus from the Seomjin River estuary in south-central Korea is also restricted to oligohaline and mesohaline waters and differs from $P$. inopinus in that it mainly occurs in oligohaline conditions (Park et al. 2005; Soh et al. 2012). Around the Japanese mainland, P. inopinus and Pseudodiaptomus nansei coexist, but the latter species is restricted to Nansei Islands (Sakaguchi and Ueda
2010; Sakaguchi et al. 2011). Recently, Sakaguchi and Ueda (2010) distinguished a separate species, P. nansei, from P. inopinus on Kyushu Island, Japan, and also identified the presence of $P$. inopinus in the eastern Sea of Japan; the population on the Pacific side of Japan consists of a complex of species that are morphologically similar but genetically distinct. Populations of $P$. inopinus also differ genetically among the western and southern/eastern parts of Korea and from Japanese populations (Soh et al. 2012). Accordingly, it would be interesting to genetically characterize populations of the putative species, $P$. inopinus, introduced into the USA in order to provide clues as to the origins of the introductions and to establish whether or not it was introduced more than once. Unlike $P$. inopinus, $P$. poplesia has not been reported as an introduced species in any location. This is interesting since the two species nearly always co-occur in the Mankyung River estuary, and $P$. poplesia co-occurs in Chinese estuaries 


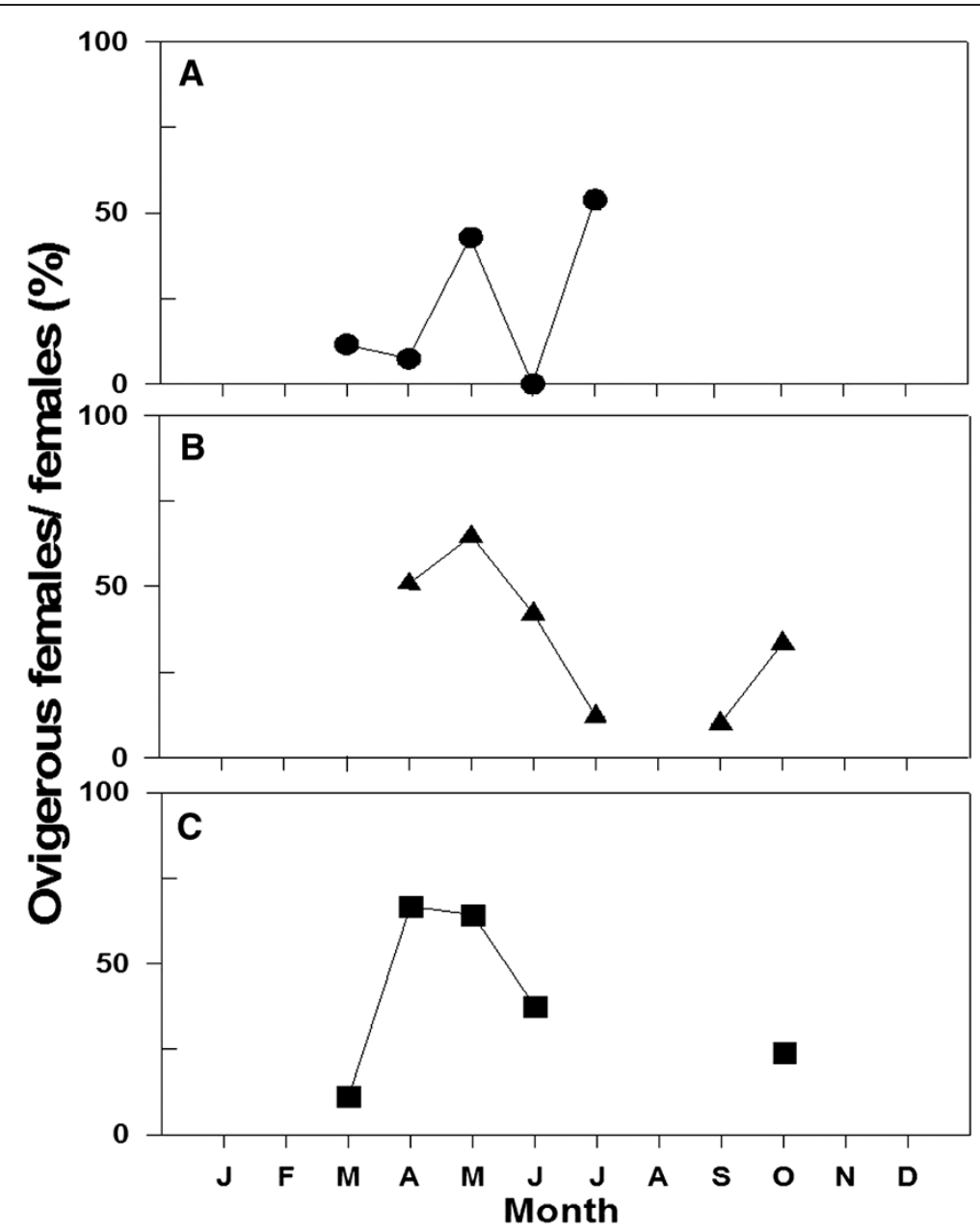

Figure 9 Seasonal variations in the composition of ovigerous adult females of $P$. poplesia. (A) Oligohaline, (B) mesohaline, and (C) polyhaline.

with Pseudodiaptomus forbesi and/or P. inopinus (Shen and Song 1979; Tan et al. 2004).

\section{Conclusions}

In this study, the annual maximal peak abundance of $P$. poplesia occurred during spring, when Chl $a$ concentrations were highest $(>150 \mu \mathrm{g} / \mathrm{L})$. Food conditions at that time may be sufficient to allow the coexistence of $P$. poplesia and P. inopinus. However, there may be more competition for food between the two species when Chl $a$ concentrations decrease in fall $(<30 \mu \mathrm{g} / \mathrm{L})$. Under these conditions, differences in their body sizes and shapes would likely be a significant factor in partitioning their food niches. In addition, $P$. poplesia has an enlarged 'naupliar eye', which could be more effective in food selectivity, while P. inopinus has two small, ordinary naupliar eyes.

P. poplesia occurs under stenohaline conditions and is adapted to a narrower salinity range than species adapted for euryhaline conditions, such as $P$. inopinus. This provides a plausible reason why $P$. poplesia has not been introduced to estuaries of the Pacific coast of the USA, unlike other Asian estuarine species (Cordell and Morrison 1996; Orsi and Ohtsuka 1999).

\section{Competing interests}

The authors declare that they have no competing interests.

\section{Authors' contributions}

EP carried out the design of the study; performed the sampling, analysis of specimens, and statistical analysis; and drafted the manuscript. JC participated in the analysis of data and discussion. HS conceived of the study and participated in its design and coordination. All authors read and approved the final manuscript.

\section{Acknowledgements}

This work was supported by a grant from the National Fisheries Research and Development Institute (Busan, South Korea) for the senior author. The authors acknowledge Prof. Ilsu Choi (Chonnam National University, Gwangju, South Korea) for his help with the statistical analysis of data and Prof. Hae-Lip Suh (Chonnam National University, Gwangju, South Korea) for his helpful comments on an earlier version of the manuscript. 


\section{Author details}

'Department of Oceanography, Chonnam National University, Gwangju 500-757, South Korea. '2Department of Life Science, Hanyang University, Seoul 133-791, South Korea. ${ }^{3}$ School of Aquatic and Fishery Sciences, University of Washington, Box 355020, Seattle, WA 98195-5020, USA. ${ }^{4}$ Faculty of Marine Technology, Chonnam National University, Yeosu 550-749, South Korea.

Received: 24 October 2012 Accepted: 8 February 2013 Published: 23 August 2013

\section{References}

Afifi A, Clark V, May S (2004) Computer-aided multivariate analysis, 4th edition. Chapman and Hall/CRC, New York

Bollens SM, Cordell JR, Avent S, Hooff R (2002) Occurrences, causes and consequences of zooplankton invasions: a brief review, plus two case studies from the northeast Pacific Ocean. Hydrobiologia 480:87-110

Chang CY (2009) Inland-water Copepoda. Illustrated encyclopedia of fauna and flora of Korea, vol 42. Jeonghaeng-sa/Ministry of Education, Seoul

Chang CY, Kim HS (1986) The freshwater Calanoida (Crustacea: Copepoda) of Korea. Kor J Syst Zool 2:49-62

Chen Q, Zhang S (1965) The plankton copepods of the Yellow Sea and the East China Sea. I. Calanoida. Stud Mar Sin 7:20-31

Cordell JR, Morrison SM (1996) The invasive Asian copepod Pseudodiaptomus inopinus in Oregon, Washington, and British Columbia estuaries. Estuaries 19:629-638

Cordell JR, Morgan CA, Simenstad CA (1992) Occurrence of the Asian calanoid copepod Pseudodiaptomus inopinus in the zooplankton variability in a turbid environment: the Gironde estuary (France). Estuar Coast Shelf Sci 64:171-184

Cordell JR, Rasmussen M, Bollens SM (2007) Biology of the introduced copepod Pseudodiaptomus inopinus in a northeast Pacific estuary. Mar Ecol Progr Ser 333:213-227

Cordell JR, Bollens SM, Draheim R, Sytsma M (2008) Asian copepods on the move: recent invasions in the Columbia-Snake River system, USA. ICES J Mar Sci 65:753-758

Cordell JR, Tear LM, Bollens SM (2010) Modelling physico-chemical factors affecting occurrences of a non-indigenous planktonic copepod in northeast Pacific estuaries. Biol Invasions 12:1427-1445

Day JW, Hall CA, Kemp WM, Arancibia AY (1989) Estuarine ecology. Wiley, New York

Greenwood JG (1981) Occurrences of congeneric pairs of Acartia and Pseudodiaptomus species (Copepoda, Calanoida) in Moreton Bay, Queensland. Estuar Coast Shelf Sci 13:591-596

Hutchinson GE (1967) A treatise on limnology, vol 2. Wiley, New York Jeffries HP (1962) Copepod indicator species in estuaries. Ecology 43:730-733

Laprise R, Dodson JJ (1993) Nature of environmental variability experienced by benthic and pelagic animals in the St. Lawrence Estuary, Canada. Mar Ecol Progr Ser 94:129-139

Lee JM, Yoon HJ, Chang CY (2007) A faunistic study on the brackish-water calanoid copepods from South Korea. Kor J Syst Zool 23:135-154

Maly EJ, Maly MP (1974) Dietary differences between co-occurring calanoid copepod species. Oecologia 17:325-333

Oka SI, Saisho T, Hirota R (1991) Pseudodiaptomus (Crustacea, Copepoda) in the brackish waters of mangrove regions in the Nansei Islands, southwestern Japan. Bull Biogeogr Soc Jpn 46:83-88

Orsi JJ, Ohtsuka S (1999) Introduction of the Asian copepods Acartiella sinensis, Tortanus dextrilobatus (Copepoda: Calanoida), and Limnoithona tetraspina (Copepoda: Cyclopoida) to the San Francisco Estuary, California, USA. Plankt Biol Ecol 46:128-131

Park EO, Suh HL, Soh HY (2005) Seasonal variation in the abundance of the demersal copepod Pseudodiaptomus sp. (Calanoida, Pseudodiaptomidae) in the Seomjin River estuary, southern Korea. Kor J Environ Biol 23:367-373

Poulet SA (1976) Feeding of Pseudocalanus minutus on living and non-living particles. Mar Biol 34:117-125

Sakaguchi SO, Ueda H (2010) A new species of Pseudodiaptomus (Copepoda: Calanoida) from Japan, with notes on the closely related $P$. inopinus Burchhardt, 1913 from Hyushu Island. Zootaxa 2623:52-68

Sakaguchi SO, Ueda H, Ohtsuka S, Soh HY, Yoon YH (2011) Zoogeography of planktonic brackish-water calanoid copepods in western Japan with comparison with neighboring Korean fauna. Plankt Benthos Res 6:18-25

Sandercock GA (1967) A study of selected mechanisms for the co-existence of Diaptomus spp. in Clarke Lake, Ontario. Limnol Oceanogr 12:97-112
SCOR-UNESCO (1980) Determination of chlorophyll in seawater. UNESCO technical papers in marine science 35. UNESCO, Paris

Shang X, Wang G, Li S, Guo D (2007) Preliminary study of the retention mechanism of planktonic copepods in the Jiulong Estuary in China. Acta Oceanol Sin 26:156-163

Shen CJ, Song DX (1979) Calanoida, Sars, 1903. In: Research Group of Carcinology, Institute of Zoology, Academia Sinica (ed) Fauna Sinica, Crustacea: freshwater Copepoda. Science Press, Beijing

Soh HY, Suh HL, Yu OH, Ohtsuka S (2001) The first record of two demersal calanoid copepods, Pseudodiaptomus poplesia and P. nihonkaiensis in Korea, with remarks on morphology of the genital area. Hydrobiologia 448:203-215

Soh HY, Kwon SW, Lee W, Yoon YH (2012) A new Pseudodiaptomus (Copepoda, Calanoida) from Korea supported by molecular data. Zootaxa 3368:229-244

Suh HL, Soh HY, Cha SS (1991) Salinity and distribution of zooplankton in the estuarine system of Mankyong River and Dongjin River. J Oceanol Soc Kor 26:181-192

Sullivan BK, McManus LT (1986) Factors controlling seasonal succession of the copepods Acartia hudsonica and A. tonsa in Narragansett Bay, Rhode Island: temperature and resting egg production. Mar Ecol Progr Ser 28:121-128

Tan Y, Huang L, Chen Q, Huang X (2004) Seasonal variation in zooplankton composition and grazing impact on phytoplankton standing stock in the Pearl River Estuary, China. Cont Shelf Res 24:1949-1968

Ueda H (1987) Temporal and spatial distribution of the two closely related Acartia species A. omorii and A. hudsonica (Copepoda, Calanoida) in a small inlet water of Japan. Estuar Coast Shelf Sci 24:691-700

Ueda H, Terao A, Tanaka M, Hibino M, Islam MS (2004) How can river-estuarine planktonic copepods survive river floods? Ecol Res 19:625-632

Uye S, Shimazu T, Yamamuro M, Ishitobi Y, Kamiya H (2000) Geographical and seasonal variations in mesozooplankton abundance and biomass in relation to environmental parameters in Lake Shinji-Ohashi River-Lake Nakaumi brackish-water system, Japan. J Mar Syst 26:193-207

Wooldridge T, Melville-Smith R (1979) Copepod succession in two South African estuaries. J Plankt Res 1:329-341

doi:10.1186/1810-522X-52-7

Cite this article as: Park et al:: Occurrence characteristics of two sibling species, Pseudodiaptomus inopinus and Pseudodiaptomus poplesia (Copepoda, Calanoida, Pseudodiaptomidae), in the Mankyung River estuary, South Korea. Zoological Studies 2013 52:7.

\section{Submit your manuscript to a SpringerOpen ${ }^{\odot}$ journal and benefit from:}

- Convenient online submission

- Rigorous peer review

- Immediate publication on acceptance

- Open access: articles freely available online

- High visibility within the field

- Retaining the copyright to your article

Submit your next manuscript at $>$ springeropen.com 